\title{
IMAGES (HOLY AND OTHERWISE): DOSTOEVSKIAN SUBTEXTS IN CONTEMPORARY RUSSIAN CINEMA
}

\author{
KIRSTEN RUTSALA \\ University of Oklahoma \\ krutsala@ou.edu
}

ABSTRACT

This article focuses on the heroines of two recent Russian films: Natalia in Vera Storozheva's Traveling with Pets (Путешествие с домашними животными) (2007) and the title character of Andrei Zviagintsev's Elena (Елена) (2011). Both characters bear striking resemblances to figures from Dostoevsky's works, among them "A Gentle Creature" ("Кроткая") and The Brothers Karamazov. By analyzing the echoes of Dostoevskian imagery, character development, and themes in these two films, I investigate how contemporary Russian filmmakers respond to and diverge from significant cultural references and tropes.

One particularly fruitful line of inquiry involves the shared imagery of religious icons. Holy images abound in Dostoevsky's fictional universe, especially the icon of the Mother of God. For instance, the title character of "A Gentle Creature" holds an icon in her hands while committing suicide, an ambiguous act encompassing both despair and spiritual liberation. While Natalia in Traveling with Pets is a true innocent, she experiences guilt for the "sin" of not loving her husband. The priest she consults gives her an icon of the Mother of God. Unlike Dostoevsky's character, however, Natalia does not succumb to despair. Instead, she experiments with various forms of liberation from her oppressive past, settling finally on modeling herself after the image of the Mother of God. Natalia adopts a boy from the orphanage she herself was raised in, and we last see her dressed in blue (the color associated with the virgin Mary), gazing at her new son with adoration.

Elena also seeks guidance from the church after her husband has a heart attack, and she is told to place candles at the icons of the Mother of God and St. Nikolai. However, her attempts to find solace in the church fail. Although she seems to possess genuine affection for her husband, Elena's strongest emotional attachment remains to her son and grandchildren. Indeed, her dedication to motherhood leads her to commit murder. Natalia may be seen as an alternative version of the gentle creature who survives and thrives, achieving personal independence and emotional transformation, but Elena represents an entirely different and darker path. While the gentle creature comes close to murdering her husband, in the "duel" scene, Elena shows us another variation of the storyline: she does murder her wealthy husband in order to save her son from poverty and her grandson from the army. While Natalia represents a triumphant version of the gentle creature whose maternal instinct saves and transforms her, Elena becomes an even more tragic figure than Dostoevsky's heroine.

KEY WORDS: contemporary Russian cinema; Holy images; Dostoevsky.

Dostoevsky's heroines inhabit a unique space in the Russian cultural landscape, inspiring heated scholarly debate, radically divergent interpretations, and passionate followings. Sonya Marmeladova, Nastassia Filippovna, Grushenka, and other characters have been variously read as evidence of Dostoevsky's alleged misogyny (Barbara Heldt and others), his attempt to grapple with "the woman question", and even of his essential lack of interest in women (Nikolai Berdyaev). Two recent Russian films, Vera Storozheva's Traveling with Pets (Путешествие с домашними животными) (2007) and Andrei Zviagintsev's 
Elena (Елена) (2011) engage in a subtle dialogue with Dostoevsky, as the filmmakers recast his fictional universe and present twenty-first century versions of some of his female characters. The films respond to themes and tropes from Dostoevsky's discourse, including silence, power imbalances, violence, and moral transgressions. Through the Dostoevskian subtext these films confront these tropes, in some cases reinforcing and in others rejecting or significantly revising them.

The main character of Traveling with Pets seems almost to have been plucked from the pages of a Dostoevsky novel. Natalia was raised in an orphanage and "sold as a slave" at the age of sixteen to a silent man she refers to only as "the master" (хозяин). Her life with him is one of drudgery and bondage in a desolate shack by the railroad tracks, and yet she retains an almost uncanny innocence. She immediately calls to mind such characters as Sofia Ivanovna, Fyodor Karamazov's second wife, who also was also an orphan married at sixteen to a man with dubious intentions. Dostoevsky describes Sofia Ivanovna as innocent, meek, gentle, uncomplaining, humble - all adjectives that suit Natalia as well. The film character also has much in common with Dostoevsky's Кроткая, the "meek one" or "gentle creature", another orphaned sixteen-year-old who enters a marriage of convenience, in her case with a tyrannical pawnbroker. Despite clear connections to these characters, significant distinctions emerge as well. Trapped in miserable marriages, Dostoevsky's characters find liberation only through illness and death. Sofia Ivanovna develops a "feminine nervous disorder" and eventually dies; the unnamed "gentle creature" also becomes seriously ill though chooses suicide in order to escape her intolerable life. Through Natalia, however, we are given a glimpse into an alternative plot. Rather than succumbing to an early death from illness or suicide, she lives with her "master" for nineteen years of servitude, evidently resigned to her lot. His death from a heart attack releases her suddenly into the world.

While the gentle creature contemplates various means of escape from her life with the pawnbroker (infidelity, murder, and finally suicide), Natalia is given the opportunity to search for an authentic identity outside the bonds of an unequal marriage. Significantly, Natalia retraces the gentle creature's steps from orphanhood to marriage and beyond, as though rewriting the course of her life. Natalia literally tries on various costumes to represent the roles she explores: a white wedding dress to symbolize a return to a state of purity and innocence (her life before marriage), a provocative red outfit in which she attracts considerable male attention, etc. Her relationship with the passing truck-driver Sergei may be seen as both a symbolic form of "infidelity" to her late husband (and thus a parallel to the gentle creature's interactions with Efimovich, which to some extent constitutes emotional unfaithfulness to the pawnbroker) and also an attempt to correct the past, to create a relationship on more equal terms. There is even a significant parallel to the "duel" scene in 
"The Gentle Creature", in which the heroine holds a gun to the pawnbroker's temple, while he feigns sleep. The pawnbroker feels exhilarated by the experience, convinced that he has "won" the duel by proving that he is not afraid of death and that his apparent courage is the reason his wife does not kill him. It never occurs to the pawnbroker that his wife hesitates and ultimately decides against shooting him because it would be an immoral act; this moment reveals at least as much about the narrator's character as about the heroine's. In the parallel scene in Traveling with Pets, Natalia points a gun at Sergei after he refuses to leave her house following their first sexual encounter. She even fires into the floor to demonstrate the seriousness of her intentions. This scene also calls to mind Dounya's final encounter with Svidrigailov in Crime and Punishment in which she fires a revolver at him twice, in a desperate attempt to escape him; the first shot misses and the second misfires. Rather than firing a third time, Dounya flings the gun away and Svidrigailov relents, allowing her to leave. The tone of the scene in Traveling with Pets is far removed from this drama in Crime and Punishment or the tense moments in "The Gentle Creature", when the heroine considers murdering her husband and he knows how close to death he is. In contrast, Natalia seems to inhabit a different psychological space to Dostoevsky's intense realm of moral choices. She does not weigh her options, agonizing about the morality of her actions. The gun in her hands is merely a symbol of brute power, which she knows Sergei will respond to. She is concerned with cause and effect, not with the implications behind her actions. Would Natalia have shot Sergei if he had not reacted to the warning shot? Sergei himself clearly considers it a bluff on her part and forgives her easily enough, returning to her several more times in the course of the film. The audience may well agree with him: Natalia is shown above all as warm and nurturing, inarticulate but genuinely concerned with the problem of sin and wrongdoing. At the same time, her growing sense of independence and autonomy causes her to call into question the bedrock basics of her existence. The slight doubt we may feel about Natalia's potential to commit murder again underscores the Dostoevskian discourse of the film. In the wrong circumstances, she could impulsively transgress the moral law, stepping over that invisible boundary as so many characters in Dostoevsky's texts do.

Middle-aged, with an adult son from her first marriage and two grandchildren, Elena in Zviagintsev's film may not seem at first glance to have anything in common with Sofia Ivanovna or the heroine of "Кроткая". Yet she too is a "gentle creature", who enters a marriage defined by substantial power imbalances and class distinctions. A nurse by profession, she marries a wealthy businessman who was originally her patient. Although we never learn the details of Vladimir's professional life, his wealth in post-Soviet Russia hints at the same moral ambiguity that Dostoevsky intends by assigning the profession of pawnbroker to the narrator of "The Gentle Creature". Elena and Vladimir's life together seems not unlike a business transaction, with Elena continuing her 
role as nurse and housekeeper. Indeed, in the film's opening scenes, her exact status is unclear, and it is only gradually that the viewer understands that Elena is Vladimir's wife. She maintains the household, serves her husband, cleans, cooks, and shops for him, in exchange for a certain amount of security (though she also retains some degree of financial independence, collecting the pension owed her for her years of work). Although she evidently feels genuine affection for Vladimir, and the film makes it clear that their relationship includes a sexual element, Elena's strongest emotional attachment remains to her son and grandchildren. When Vladimir refuses the money that would allow her grandson to avoid army service and then plans to rewrite his will in favor of his wayward daughter, cutting off the possibility of future financial security for Elena and her loved ones, the heroine chooses a path of violence: she poisons Vladimir. Unlike the heroine of "The Gentle Creature", who contemplates murdering her husband but cannot go through with it, Elena methodically plans and carries out the murder, employing her medical knowledge to deadly effect. Through this action of transgressing the moral law, Elena appears to be a surprising combination of two other characters from Dostoevsky's fiction: Raskolnikov and Sonya Marmeladova. The calculated murder of Vladimir may remind us of Raskolnikov more obviously than Sonya, but Elena's actions also recall Sonya's conscious choice of prostitution in order to benefit her family. Of course, Elena cannot be seen as a pure figure of redemptive suffering like Sonya, and her murder of Vladimir crosses the line from sacrificing herself to taking someone else's life. The decision to kill Vladimir may seem entirely mercenary, utterly cold-blooded, and as morally corrupt as Raskolnikov's crime. At the same time, Elena can be seen as a desperate woman whose maternal instinct to provide for her son and grandchildren prompts her to abandon her moral compass, an impulse that shares something in common with Sonya's choice to become a prostitute in order to feed her family and to save her little sister from a similar fate. The fact that Elena's son and grandson seem utterly unworthy of her moral sacrifice, expressing only half-hearted affection for her and evidently unwilling to take any step to improve their position, further condemns her to a fate more tragic than any of Dostoevsky's heroines.

One particularly fruitful line of inquiry, linking these two films to Dostoevsky's works, involves the shared imagery of religious icons. Holy images abound in Dostoevsky's fictional universe, especially the icon of the Mother of God. For instance, Sofia Ivanovna in The Brothers Karamazov has a special devotion to this icon; her son Alyosha has a vivid childhood memory of her praying before it, weeping violently, asking the Mother of God to protect her child. Fyodor Karamazov recalls his cruelty in insulting the icon and spitting on it in front of his wife; when he tells the story years later, Alyosha reacts exactly as his mother had, by falling into a paroxysm of uncontrollable sobbing. But even the cruel Fyodor Karamazov is somehow moved by the power of the icon; he gives the icon to Alyosha and allows him to return to the 
monastery, in a sense blessing Alyosha's Christian journey. At the beginning of "A Gentle Creature", the title character attempts to pawn such an icon: “Богородица с младенцем, домашний, семейный, старинный, риза серебряная золоченая - стоит - ну, рублей шесть стоит” (“a Madonna and child, an old-fashioned, homely one, and the setting was silver gilt, worth well, six rubles perhaps"). The icon is precious to her because it once belonged to her parents, and she parts with it unwillingly, due to financial necessity, and remains determined to redeem it. Her emotional attachment to the icon persists throughout the story, and at the conclusion she holds it in her hands while throwing herself from the window, an ambiguous act encompassing both despair and spiritual liberation. This image - of a woman leaping to her death, holding an icon - was the inspiration for Dostoevsky's story when he read a newspaper account of a seamstress who committed suicide precisely this way. Dostoevsky calls it "a meek, humble suicide" (какое-то кроткое, смиренное самоубийство). It is precisely the icon that sets this death apart for Dostoevsky: “Тут даже, видимо, не было никакого ропота или попрека: просто - стало нельзя жить. 'Бог не захотел' и - умерла, помодившись” (“Here it seems there wasn't a single murmur or reproach: simply it became impossible to live. 'God didn't want it' - and she died, praying').

When Vladimir has a heart attack in Zviagintsev's film, Elena goes to church to pray for him. So unfamiliar is she with church etiquette that she must be reminded to cover her head. Nor does she know where to place candles; a woman working at the church directs her to the icons of the Mother of God and St. Nikolai (Николай угодник) and tells her how to pray. It is possible to interpret her churchgoing as an empty, dutiful gesture. In post-Soviet Russia, the Orthodox Church has reclaimed a central position in the country. A quick visit to the church may be just another of the trappings of contemporary life for a wealthy Muscovite, no more meaningful than Elena's trips to the supermarket or Vladimir's outings to his upscale gym. However, at this point in the film, Elena's affection for Vladimir is evident and her prayers for his recovery seem genuine and heartfelt. But praying before the icons clearly has no lasting spiritual effect on Elena, since she plans and carries out murder not long after her visit to the church. An interesting moment occurs after she gives Vladimir the fatal dose of medication but before he actually dies. The camera lingers on a wall of family photographs, slowly closing in on a picture that appears to be Elena as a young woman: pretty, smiling broadly, in some outdoor setting (on either side of this picture hang photos of Elena's son and Vladimir's daughter; Elena is literally in the middle of these two figures whose opposing interests motivate her decision to murder Vladimir). The family picture has taken the place of the religious icon; material interests take precedence over spiritual values. The photograph also emphasizes how little we actually know of Elena; the life she led before becoming the subservient wife/housekeeper of a wealthy man is out of our reach, and her inner transformation from affectionate 
companion to calculating killer is as complete as her outward transformation from the young woman in jeans to the middle-aged hausfrau in shapeless dresses.

Unlike the gentle creature, who essentially transforms herself into an icon, "eloquent, albeit mute, testimony to her suffering and her imitation of Christ" (Jackson 1981: 256), framed in the window before leaping to her death, Elena's brief encounter with traditional religion does not influence her in the long run. Although her motherhood is the defining feature of her life, and her overwhelming instinct to protect her son and grandchildren leads her to commit murder, Elena as a mother figure is far removed from the Orthodox image of the Mother of God. In some parts of Europe, the movie posters for this film consisted of a picture of Elena with her toddler grandson asleep in her arms, a clear reference to religious iconography. But one can only view Elena as an ironic version of the idealized motherhood represented by the Mother of God. When Elena sobs at her husband's funeral, her visible grief may be equal parts guilt and a desire to look the part of the grieving widow. In one of the most telling moments of the film, when Elena visits her son and his family after Vladimir's death, the electricity fails. Suddenly plunged into darkness, Elena reaches for her son's hand and grips it tightly. Her terror is disproportionate to the actual situation but understandable to the viewer who knows the full story. The darkness represents Elena's spiritual void, and it is not confined to her alone. When her son goes out to the hallway to investigate what is happening, someone says the lights are out in the whole building and another voice responds, "In the whole world". Moments later, we see Elena's seventeen-yearold grandson and his friends attack another group of young men for no apparent reason. The spiritual darkness extends to every character in the film, an unrelievedly bleak indictment of the contemporary world.

Natalia in Traveling with Pets also seeks guidance from the church after the death of her husband. Unlike Elena, who sobs uncontrollably during her husband's funeral, Natalia remains dry-eyed throughout the funeral service. The kind but somewhat detached priest even remarks upon it: "Почему ты не плачешь совсем?" ("Why aren't you crying at all?) Natalia asks, "А это обязательно нужно?" ("Is that absolutely necessary?") and the priest answers, “Да нет, не обязательно" ("No, no, it's not necessary") without inquiring further. He then gives her an icon of the Mother of God, "the softener of evil hearts" (Умягчение злых сердец), traditionally an icon intended to dispel anger against one's enemies. Natalia's unemotional response to her husband's death indicates to the priest that she is harboring anger toward him.

When she returns to the church and confesses that she never loved her husband, that she hated him so much she could have killed him, the priest offers little in the way of spiritual consolation, saying only, "Жить надо по любви. И любовью” (“One must live for love. And by love”). When Natalia asks how to do that, he doesn't explain further. Instead, he asks Natalia to help 
him with the work he is doing: painting the door of the church. The restoration of this dilapidated village church, which is ongoing throughout the film, represents both Natalia's personal spiritual awakening (recognizing her "sin" of not loving her tyrannical husband, the softening of her heart) and perhaps also a return to religious traditions for Russia as a whole. After Natalia experiments with and rejects various forms of liberation from her oppressive past (she tries on the role of "virgin" in her wedding dress, "whore" in her bright red ensemble [Monastireva-Andsell 2008], the possibility of a future married to Sergei), she settles on another course: to become a mother. Returning to the orphanage she grew up in, Natalia adopts a red-haired boy named Grigory. Unlike Dostoevsky's gentle creature, Natalia does not succumb to despair; unlike Elena, her maternal instincts are presented as entirely positive and lifeenhancing. She models herself after the image of the Mother of God and becomes a living icon. Her "virginal" motherhood (she acquires a son without engaging in a sexual relationship with the father) further underscores the link to the Mother of God. On her way to the orphanage Natalia encounters a newly married couple, the bride in her wedding dress visibly pregnant, an overt image of new life and hope for the future. Significantly, the couple interacts with Natalia as though she too is a symbolic figure whose appearance blesses their marriage and child; the groom pledges to name their unborn child after her if it turns out to be a girl. Our last view of Natalia shows her dressed in blue (the color associated with the virgin Mary), gazing at her new son with adoration.

In January 1876, several months before producing "A Gentle Creature", Dostoevsky writes as follows in his Diary of a Writer, after learning about the Russian Society for the Protection of Animals: "И действительно, не одни же ведь собачки и лошадки так дороги “Обществу“, а и человек, русский человек, которого надо образить" (“And in fact the Society is concerned not only with poor dogs and horses; man too - Russian man - needs to 'image' himself"). He then goes on to give a parenthetical explanation of the verb "to image oneself": “Образить - словцо народное, дать образ, восстановить в человеке образ человеческий. Долго пьянствующему говорят, укоряя: “Ты хошь бы образил себя“. Слышал от каторжных" (“To image oneself is an expression heard among the people; it means to give an image, to restore in man his human image. One who has been drinking for a long time is told, with reproach, 'You ought to image yourself.' I heard this from the convicts" [Dostoevsky 1987: 325, translation slightly altered]). Of course, the word oбpa3 (image) also refers to icons. Dostoevsky's conceptions of образ, образить, and безобразие form a crucial part of the fabric of his texts (Jackson 1966). Thus to "image oneself" carries religious undertones, particularly as related to Orthodox tradition and practice. The word means not only to be fully human, the being created in the image of God, but to become like the most fully realized human beings: the saints whose piety, selflessness, and virtuousness brought 
them closest to God. Ordinary people revere these saints in part through the religious use of icons, which are both literal representations of individual saints and spiritual images of their virtues. They are thus both reminders of the distance between ordinary people and figures like St. Nikolai and the Mother of God, and representations or models of the highest virtues to which ordinary people can aspire. Holy icons in Dostoevsky's works often signal a character's deep spirituality (Sofia Ivanovna, Alyosha); the ambiguity of the gentle creature's suicide displays her despair but also her longing for spiritual consolation. Conversely, Dostoevsky emphasizes Fyodor Karamazov's moral corruption by relating the scene in which this character actually spits on an icon of the Mother of God in order to "knock the mysticism" out of his pious wife, though even Karamazov is moved by the power of the icon. In the visual medium of cinema, both Storozheva and Zviagintsev make use of icons to explore and reinforce similar themes of spirituality, as well as to contrast the behavior of their characters with the ideal and pure lives of the saints. As we have seen, Natalia manages to "image" herself in both senses of the word; she achieves a high degree of humanity, becoming her best possible self, and she models herself upon the icon of the Mother of God. On the other hand, Elena sacrifices her humanity in her attempt to protect her child and grandchildren. She does not "image" herself in Dostoevsky's sense or in the sense of becoming like the revered saint in an icon. Instead, she moves closer to chaos and confusion, “безобразие" (literally "imagelessness").

The female characters in Dostoevsky's works tend to be portrayed through the eyes of the male characters. Some critics see this propensity as a general trend among Russian writers of the nineteenth century: "The fictions of Russian men tended to isolate female characters from one another, attending to their interactions with men under a male observing eye" (Heldt 1987: 62). Sonya Marmeladova is silent throughout much of Crime and Punishment, observed and interpreted for the reader by her father, Raskolnikov, and Luzhin. Sofia Ivanovna mostly appears through the memories of Alyosha and Fyodor Karamazov. The pawnbroker's narrative tells us everything we know about the gentle creature, including his many misinterpretations of her motives and behavior. In contrast, we see the heroines of Elena and Traveling with Pets through their own eyes, authoring their own stories rather than being inscribed in a male narrative (de Lauretis 1984: 104). In both cases, however, they define their identities in the most traditional way possible, the state that is most emotionally and culturally charged: motherhood. Natalia certainly follows a stereotypical path to female fulfillment, and the film's overly neat conclusion is meant to be uplifting and satisfying. Elena, on the other hand, demonstrates the dark side of motherhood, following her instinct to destroy anyone who threatens her children. What might Dostoevsky have made of these characters? He might well have thoroughly approved of Natalia's selfless desire to devote her life to raising a vulnerable orphan. The spiritually barren landscape 
portrayed in Elena would undoubtedly be familiar to Dostoevsky, though without the possibility of redemption we see in his works. Perhaps he would have wanted Elena to recognize and atone for her moral transgression; if she were in fact a character in his fiction he might have sent her back to the church or provided her with a spiritual adviser to urge her toward repentance.

\section{BIBLIOGRAPHY}

De Lauretis, T. (1984), Alice Doesn't: Feminism, Semiotics, Cinema, Bloomington, Indiana University Press.

DostOeVSKY, F.M. (1972-90), Polnoe sobranie sochinenii v 30 tomakh, Leningrad, Nauka.

DostoevsKy, F.M. (1997), A Writer's Diary, ed. and trans. Kenneth Lantz, Evanston, Northwestern University Press.

HeLDT, B. (1987), Terrible Perfection: Women and Russian Literature, Bloomington, Indiana University Press.

JACKSON, R.L. (1966), Dostoevsky's Quest for Form: A Study of his Philosophy of Art, New Haven, Yale University Press.

JACKSON, R.L. (1981), "The Temptation and the Transaction: 'A Gentle Creature'", The Art of Dostoevsky: Deliriums and Nocturnes, Princeton, Princeton University Press.

MonASTIREVA-ANDSELL (2008), “One Size Does Not Fit All: Trains, Fashions, Mammals, and the Meaning of Life in Vera Storozheva's Traveling with Pets", Kinokultura. 